\title{
What are the main climate drivers for shrub growth in Northeastern Siberian tundra?
}

\author{
D. Blok $^{1, *}$, U. Sass-Klaassen ${ }^{2}$, G. Schaepman-Strub ${ }^{3}$, M. M. P. D. Heijmans ${ }^{1}$, P. Sauren ${ }^{1,2}$, and F. Berendse ${ }^{1}$ \\ ${ }^{1}$ Nature Conservation and Plant Ecology Group, Wageningen University, P. O. Box 47, 6700 AA, Wageningen, \\ The Netherlands \\ ${ }^{2}$ Forest Ecology and Forest Management, Wageningen University, P. O. Box 47, 6700 AA, Wageningen, The Netherlands \\ ${ }^{3}$ Institute of Evolutionary Biology and Environmental Studies, University of Zürich, Winterthurerstrasse 190, 8057, Zürich, \\ Switzerland \\ *Invited contribution by D. Blok, recipient of the EGU Young Scientists Poster Paper Award 2010.
}

Received: 6 December 2010 - Published in Biogeosciences Discuss.: 24 January 2011

Revised: 27 April 2011 - Accepted: 12 May 2011 - Published: 17 May 2011

\begin{abstract}
Deciduous shrubs are expected to rapidly expand in the Arctic during the coming decades due to climate warming. A transition towards more shrub-dominated tundra may have large implications for the regional surface energy balance, permafrost stability and carbon storage capacity, with consequences for the global climate system. However, little information is available on the natural long-term shrub growth response to climatic variability. Our aim was to determine the climate factor and time period that are most important to annual shrub growth in our research site in NESiberia. Therefore, we determined annual radial growth rates in Salix pulchra and Betula nana shrubs by measuring ring widths. We constructed shrub ring width chronologies and compared growth rates to regional climate and remotely sensed greenness data. Early summer temperature was the most important factor influencing ring width of $S$. pulchra (Pearson's $r=0.73, p<0.001$ ) and $B$. nana (Pearson's $r=0.46, p<0.001)$. No effect of winter precipitation on shrub growth was observed. In contrast, summer precipitation of the previous year correlated positively with $B$. nana ring width (Pearson's $r=0.42, p<0.01$ ), suggesting that wet summers facilitate shrub growth in the following growing season. S. pulchra ring width correlated positively with peak summer NDVI, despite the small coverage of S. pulchra shrubs $(<5 \%$ surface cover) in our research area. We provide the first climate-growth study on shrubs for Northeast Siberia, the largest tundra region in the world. We show that
\end{abstract}

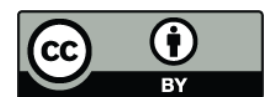

Correspondence to: D. Blok (daan.blok@wur.nl) two deciduous shrub species with markedly different growth forms have a similar growth response to changes in climate. The obtained shrub growth response to climate variability in the past increases our understanding of the mechanisms underlying current shrub expansion, which is required to predict future climate-driven tundra vegetation shifts.

\section{Introduction}

Climate change scenarios predict increasing air temperatures for the next decades, with most warming occurring at high latitudes (IPCC, 2007). Northern ecosystems will be greatly impacted by climate changes through alterations of the surface energy balance, permafrost thaw and changes in vegetation (ACIA, 2004). Vegetation changes have multiple feedbacks to the regional climate system through changes in the surface albedo, soil moisture exchange and the soil carbon balance (McGuire et al., 2006; Wookey et al., 2009). Of all plant functional types, deciduous shrubs are among the most responsive to changes in temperature by increasing their growth, as shown by many experimental warming studies across the Arctic (Chapin et al., 1995; Hobbie and Chapin, 1998; Walker et al., 2006).

Evidence for shrub expansion exists for sites in Alaska (Sturm et al., 2001b; Tape et al., 2006) and a recent increase in shrub biomass is measured at multiple sites across the Arctic (Chapin et al., 1995; Hudson and Henry, 2009; Olofsson et al., 2009). On a larger scale, circumpolar greening (Normalized Difference Vegetation Index, NDVI) trends suggest that shrub expansion is a widespread phenomenon across the

Published by Copernicus Publications on behalf of the European Geosciences Union. 
Arctic (Goetz et al., 2005; Jia et al., 2009; Tape et al., 2006). During warmer periods in the Holocene shrubs were much more abundant than today (Bigelow et al., 2003; Müller et al., 2009), indicating the potential for shrub expansion in the Arctic under current climate change scenarios (ACIA, 2004; IPCC, 2007).

Summer air temperature is known to be a crucial factor for bud-break timing in deciduous Arctic shrubs (Pop et al., 2000) and for radial growth of boreal tree species from Siberia, like Larix spp. (larch) (Hughes et al., 1999). However, little is known so far on how shrub growth rates are affected by seasonal changes in precipitation and temperature across the Arctic. Currently, the only study assessing the growth response of deciduous shrubs to climate variability in the Russian Arctic is from Salix lanata shrubs from W-Siberia, indicating a strong positive relationship between radial growth and summer temperature (Forbes et al., 2010). Other research on climate-growth relationships of Arctic shrubs include studies on dwarf shrubs from the extreme barren Arctic zone (Rayback and Henry, 2006; Rozema et al., 2009; Schmidt et al., 2006) and shrubs from alpine environments (Bär et al., 2008).

Apart from summer temperature, winter precipitation may also influence tree growth through its effect on the start of cambial activity (Kirdyanov et al., 2003; Vaganov et al., 1999). Furthermore, it is suggested that snow cover may play a crucial role in shrub expansion by causing an increase of winter soil temperatures due to the insulating properties of snow (Sturm et al., 2001a). Changes in snow cover thus can have implications for rates of soil organic matter turnover during the winter-spring period (Borner et al., 2008; Schimel et al., 2004; Sturm et al., 2005a). On a larger timescale, pollen-reconstructions suggest that the areal extent of shrub tundra can be reduced by a decrease in winter precipitation (Bigelow et al., 2003) because this exposes the shrubs more to the harsh Arctic winter conditions. However, negative relationships between snow fall and shrub growth rates have also been reported. For example, snow precipitation has been shown to correlate negatively with the radial growth of Salix arctica shrubs in Greenland (Schmidt et al., 2010).

Our general aim was to determine those climate factors that are most important for annual shrub growth and the periods when these factors are most influential in our research site in NE-Siberia. Therefore, we determined annual growth rates in Betula nana and Salix pulchra shrubs by measuring ring widths. S. pulcha and B. nana are two of the most widespread Arctic deciduous shrub species with a circumpolar distribution (Hultén, 1968), but to our knowledge have not been used before for dendroclimatological analysis. Both species can be attributed to the same plant functional group, deciduous shrubs (Chapin et al., 1996), but have a clear distinction in growth strategy (Bret-Harte et al., 2002) and hence may respond differently to climate factors and environmental changes. Our specific research questions were: (i) how does radial growth of two deciduous Arctic shrub species respond to variation in the most important climate factors, temperature and precipitation?

(ii) what is the difference in summer versus winter climate effects on shrub growth? and

(iii) can inter-annual shrub growth variability be tracked by remotely sensed NDVI data?

\section{Materials and methods}

\subsection{Sampling strategy}

During the summer of 2008 and 2009 samples of B. nana and $S$. pulchra shrubs (50 individuals per species) were collected in the Kytalyk nature reserve, $\left(70^{\circ} 49^{\prime} \mathrm{N}, 147^{\circ} 28^{\prime} \mathrm{E}\right)$, located approximately $30 \mathrm{~km} \mathrm{NW}$ from Chokurdakh in the Indigirka lowlands in northeast Siberia, Russia (Blok et al., 2010; van der Molen et al., 2007). Height and micro topography were noted for each sampled shrub. The vegetation cover in the research site consists of a mixture of graminoids, forbs, mosses and shrubs and is classified as vegetation unit G4 (tussock-sedge, dwarf-shrub, moss tundra) at the Circumpolar Arctic Vegetation Map (Walker et al., 2005). S. pulchra and B. nana shrubs cover approximately $5 \%$ and $20 \%$ of the research area, respectively (unpublished results). $S$. pulchra grows erect and up to $3 \mathrm{~m}$ tall, with few branches, whereas $B$. nana grows decumbent and low-statured, with a height up to $30 \mathrm{~cm}$ and develops many branches. $B$. nana can greatly increase its number of branches under warming treatments (Bret-Harte et al., 2001) and become rapidly dominant (Bret-Harte et al., 2008), whereas S. pulchra is not known to possess this plasticity in architectural morphology (BretHarte et al., 2002). S. pulchra grows in relatively wet patches along rivers and lakes, whereas $B$. nana grows more upland on slightly elevated and relatively dry patches. Studies on reindeer grazing effects on vegetation responses in the Arctic indicate that shrub growth rates may be heavily impacted by grazers (Olofsson et al., 2009), but no signs of grazing damage on shrubs or their wood anatomy were observed in our research area. Shrubs were cut well below the moss layer, below the root-shoot transition zone, to ensure that samples contain the oldest, first formed parts of the shrubs. Samples were air-dried before shipment to the lab for analysis.

\subsection{Dendrochronological analysis}

In the lab, thin sections (20-30 $\mu \mathrm{m})$ were prepared from two or more samples along the main stem axis of each shrub (base section and section(s) after first branch node) within each shrub individual using a GSL1 sledge microtome (MICROT L, Schenkung Dapples, Zürich, Switzerland). Missing rings are a common phenomenon in dwarf shrubs and can cause significant dating problems (Kolishchuk, 1990). The use of 
Table 1. Statistics of Salix pulchra and Betula nana ring-width residual chronologies.

\begin{tabular}{lcccccc}
\hline & mean series length (years) & mean ring width $(\mathrm{mm})$ & $n$ & $\mathrm{r}$ & $\mathrm{EPS}$ & $\mathrm{MS}$ \\
\hline Salix pulchra & $48(10)$ & $0.21(0.14)$ & 19 & 0.62 & $0.83-0.97$ & 0.48 \\
Betula nana & $46(16)$ & $0.11(0.08)$ & 19 & 0.31 & $0.58-0.90$ & 0.44 \\
\hline
\end{tabular}

$n$ : number of shrub individuals used to construct the final chronology.

r: mean correlation of each series with the mean master chronology derived from all series.

EPS: expressed population signal, indicates the representativeness of the sample size for a theoretical sample size with an infinite number of shrub individuals (Wigley et al., 1984).

MS: mean sensitivity, the mean relative change in ring-width from one year to the next (Fritts, 1976).

Values between brackets are standard deviations from the mean.

the serial sectioning method greatly reduces dating errors due to very narrow, eccentric, false or discontinuous growth rings in Arctic shrubs (Bär et al., 2006; Büntgen and Schweingruber, 2010; Woodcock and Bradley, 1994). The thin sections were stained with a safranin/astra blue mixture to enhance contrast between wood tissues, which greatly improves the detection and ability to accurately measure tree rings. After staining, samples were dehydrated by rinsing them subsequently with mixtures of $50 \%, 96 \%$ and $100 \%$ alcohol. Dehydrated samples were adhered to a microscope slide with Canada balsam, dissolved in xylol, and covered with a cover glass. The cover glass was pressed firmly to the microscope slide to ensure all air bubbles were removed from the sample. The prepared microscope slides were pressed onto a metal plate using a magnet and put in an oven at $60^{\circ} \mathrm{C}$ overnight to dry. Dried samples were removed of balsam residue using a razorblade.

Ring-widths were measured from each thin section along at least 2 radii using a LINTAB 4 tree-ring measurement device (RINNTECH, Heidelberg, Germany) with a measurement precision of $0.01 \mathrm{~mm}$, connected to a Leica MS5 stereomicroscope (40x magnification) and software (Time Series Analysis Program (TSAP) v.3.6). TSAP software was used to visually inspect and crossdate ring-width series. Crossdated ring-width series of samples from the same stem height were averaged and compared to those from another height within the same individual to check for missing or wedging rings. Eventually, mean ring-width series were calculated for each shrub. For individual S. pulchra shrubs, ring-width series were calculated from measurements taken from samples of two heights (base section, section after first branch node) as chronologies from these series yielded the highest correlation with climate variables. For B. nana shrubs, chronologies calculated from the ring-width series of the base section of each shrub contained the strongest climate signal (data not shown). However, also for B. nana, the serial sectioning method (measuring ring-widths at multiple heights) was applied (Kolishchuk, 1990) to check for missing rings and crossdating errors (Bär et al., 2006; Hallinger et al., 2010). No individuals with consistently missing rings along the whole shrub were encountered in our samples. The mean ring-width series of all shrub individuals of the two species were visually inspected and cross-dated using a va- riety of statistical checks (GLK, GSK, TVBP (modified tvalues), and COFECHA software (Grissino-Mayer, 2001; Holmes, 1983)). Only individuals that could be accurately crossdated were included in the final chronologies of the two shrub species. Per shrub species, 19 individuals were included in the final chronologies. The two shrub chronologies were evaluated by three statistical checks: the mean correlation strength between each individual and the mean chronology (r); the mean sensitivity (MS), which is the percentage change from each ring to the next (Fritts, 1976); and the expressed population signal (EPS), which is the relationship between a finite sample chronology with a hypothetical perfect chronology with infinite replication (Wigley et al., 1984).

ARSTAN v6.05 standardization software was used to perform a double-detrending procedure to remove age-related growth trends and to remove auto-correlative growth between the previous year and the next. First, a negative exponential curve or linear regression curve was fitted through the raw data, after which a 32-year cubic smoothing spline was fitted through the resulting indices, which preserves $50 \%$ of the variance at a wave-length of 32 years (Cook and Peters, 1981). After detrending and standardization procedures, standard chronologies (STD) and residuals chronologies (RES) were obtained (Table 1). The RES chronology is the same as the STD chronology but without the influence of growth from the previous year on the growth of the next year (Cook et al., 1990). We compared RES chronologies of B. nana and S. pulchra shrubs developed in this study with RES chronologies (http://www.ncdc.noaa. gov/paleo/treering.html) from Larix spp. tree samples collected by F. H. Schweingruber and with a RES chronology from W-Siberia developed by Forbes et al., 2010.

\subsection{Instrumental climate data}

Climate data from the closest meteorological station (WMO station 21946), located in Chokurdakh at $30 \mathrm{~km}$ from the research site and second closest meteorological station (WMO station 24266), located in Verkhoyansk at $660 \mathrm{~km}$ from the research site, were used to compare against our shrub chronologies (http://climexp.knmi.nl/). Raw daily precipitation and temperature data for the period 1944-2006 were available (Klein Tank et al., 2002). Snow melt data were 
available for the period 1992-2006. An often applied procedure to identify climate signals in ring-width data is by using monthly average climate data, but this is a rather coarse time interval to explore the climate-growth relationship during the short Arctic summer. Instead, we performed pentad analyses (Hughes et al., 1999; Kirdyanov et al., 2003; Panyushkina et al., 2003; Vaganov et al., 1999) to assess the period of the maximal growth response to temperature for both S. pulchra and $B$. nana shrubs. A pentad is the average temperature during a period of 5 consecutive days. By applying a flexible shifting time-window analysis, pentads with significant relation to the RES shrub chronologies were averaged to find the period of maximum correlation between the shrub chronologies and temperature.

Vegetation summer greenness in our research area was evaluated with Normalized Difference Vegetation Index (NDVI) data, measured by the Advanced Very High Resolution Radiometer (AVHRR) satellites. NDVI records have been shown to be a good measure for tundra plant productivity and correspond with variations in summer warmth (Goetz et al., 2007; Raynolds et al., 2008). NDVI data for the period 1981-2006 were obtained from the Global Inventory Modeling and Mapping Studies (GIMMS) dataset (http:// glcf.umiacs.umd.edu/data/gimms/) (Tucker et al., 2005). We analyzed biweekly NDVI data of the Arctic growing season period (June-August) and correlated NDVI data against the RES shrub chronologies. The spatial resolution of the GIMMS NDVI-record was $8 \mathrm{~km}$. We calculated average biweekly NDVI values for multiple spatial scales: (a) Research shrub sampling site (1 pixel, $\left.16 \mathrm{~km}^{2}\right)$; b) research area including sampling site (4 pixels, $\left.64 \mathrm{~km}^{2}\right)$; Kytalyk nature reserve (420 pixels, $6720 \mathrm{~km}^{2}$ ).

\subsection{Data analysis}

Pearson's correlation coefficients $r$ were calculated to find the climate variable (precipitation, temperature) and period to which shrub growth is most sensitive. A correction for multiple testing was applied by using the false discovery rate procedure to control for type I errors (Verhoeven et al., 2005). A linear regression analysis was performed with peak growing season NDVI of the research area (average NDVI values of four pixels with a spatial resolution of $8 \mathrm{~km}$ ) as a function of summer temperature for the period 1981 to 2006 (Chokurdakh weather station data). Linear regression was performed to explain similarities between the shrub chronologies developed in this study and chronologies developed from regional Larix spp. trees, with the Pearson's $r$ values between shrub and Larix spp. RES chronologies as dependent variable and geographical variables as explanatory variables. Data were ln- or square root-transformed where needed to achieve normal distribution. All statistical analyses were performed using SPSS for windows v.17.0.
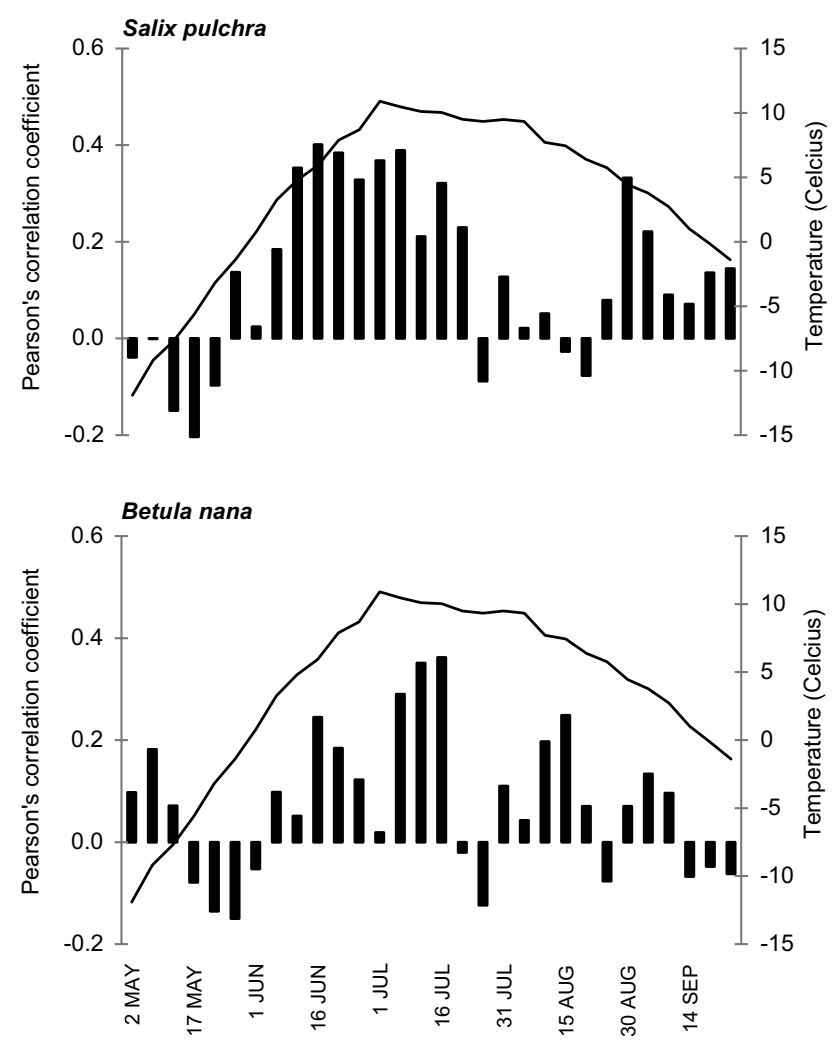

Fig. 1. The vertical bars show Pearson's correlation coefficients between the mean average temperature of 5-day periods (pentads) measured at the Chokurdakh meteorological station for the period 1948-2006, and the residual chronologies of Salix pulchra and Betula nana. The continuous line shows average daily temperature data for the period 1948-2006 from the meteorological station in Chokurdakh.

\section{Results}

Residual (RES) chronologies were established for the two shrub species, with the $S$. pulchra chronology showing higher inter-series correlation than the B. nana series (Table 1). The large variability in ring width between $B$. nana individuals resulted in relatively low EPS values (0.58-0.83), especially in the early part of the $B$. nana RES chronology (1948-1970). B. nana and S. pulchra RES chronologies correlated significantly with each other $(r=0.44, p<0.001$, $n=59$ years).

We calculated which climate factor (temperature or precipitation) and seasonal period was most important for annual growth of B. nana and S. pulchra. Significant correlations with radial growth rates were detected only for summer climate variables. No correlation of winter precipitation or winter temperature with shrub growth was detected (Table 2). Both deciduous shrub species were most responsive to average summer temperatures of the same time window: the period immediately following snowmelt (17 June19 July) (Fig. 1). The S. pulchra chronology showed a high 

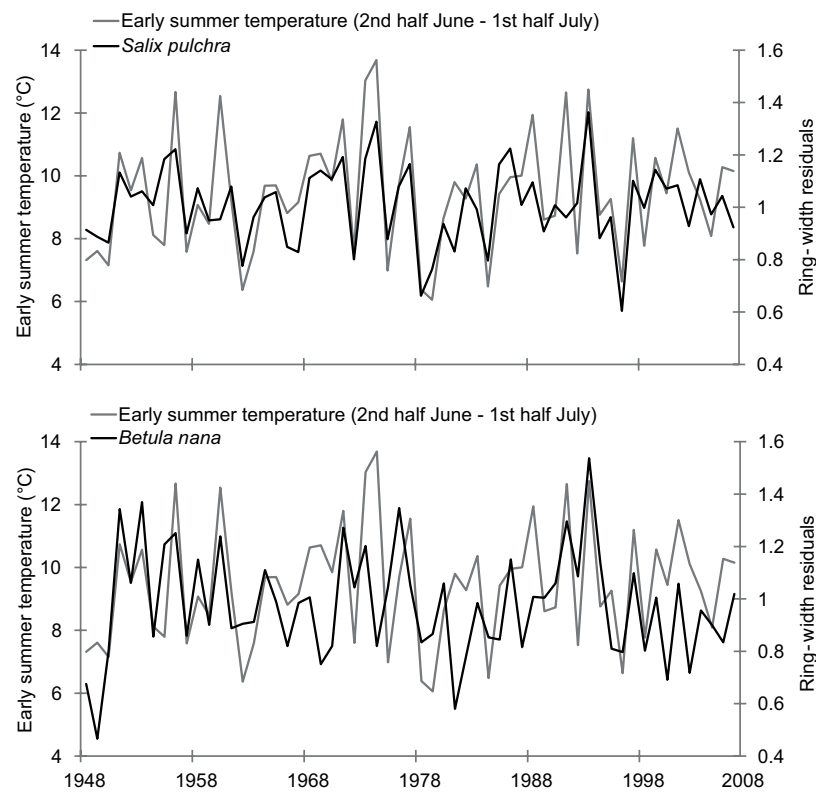

Fig. 2. The black lines show Salix pulchra and Betula nana residual ring-width chronologies. The grey lines show the mean summer temperature (17 June-19 July) for the period 1948-2006.

correlation with early summer temperature $(r=0.73, p<$ 0.01 , Table 2), similar to correlation strengths found between summer temperature and regional Larix spp. chronologies (Hughes et al., 1999; Kirdyanov et al., 2003). Besides earlysummer temperature, summer precipitation (June-August) of the year preceding ring formation had a positive influence on the radial growth of $B$. nana $(r=0.42, p<0.01$, Table 2). Analysis of long-term summer temperature data from the meteorological station in Chokurdakh for the period 1948-2006 showed a slight positive trend (trend line slope $=0.014{ }^{\circ} \mathrm{Cyr}^{-1}$, Fig. 2), comparable with observations on summer temperature trends from W-Siberia by Forbes et al., (2010). Average yearly winter precipitation (October-April) and standard deviation in our research site during 1948-2006 was $87 \pm 28 \mathrm{~mm}$, with a positive trend $\left(0.12 \mathrm{~mm} \mathrm{yr}^{-1}\right)$. The S. pulchra RES chronology also correlated with early summer temperature data from the second closest meteorological station, located in Verkhoyansk at approximately $660 \mathrm{~km}$ southwest from the research site $(r=0.49, p<0.01)$.

We tested to what spatial extent our shrub chronologies may be representative by comparing them to a tree-ring network that covers our research region with a relatively high spatial density, in contrast to the sparse meteorological data available for this region. B. nana and S. pulchra RES chronologies showed significant correlations with respectively, four and seven out of the 20 Larix spp. chronologies from North Yakutia. The $S$. pulchra chronology correlated best with the regional North Yakutia chronology $(r=$ $0.78, p<0.01$ ), whereas the $B$. nana chronology correlated best with the Bilibina chronology $(r=0.47, p<0.05)$, con-

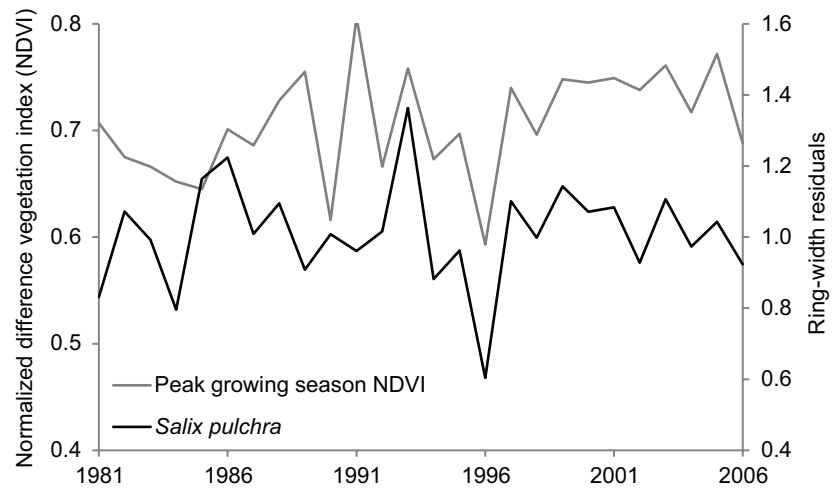

Fig. 3. The grey line shows peak growing season (2nd half July) greenness (NDVI) values for the Kytalyk research area in NESiberia. NDVI was calculated as the average of four pixels, with each pixel giving a NDVI value for an area measuring 8 by $8 \mathrm{~km}$. The black line shows the Salix pulchra residual chronology.

structed from samples located at $880 \mathrm{~km}$ from our research site (Table 3). For S. pulchra, similarities with the other chronologies were explained by latitude and longitude, as shown by the results of a multiple linear regression test (Table 4). For B. nana, longitude explained most of the similarity with the tree-ring chronologies, followed by elevation. Up to $57 \%$ of the variation in similarities of the shrub chronologies with the Larix spp. chronologies could be explained by geographical parameters.

The $S$. pulchra RES chronology showed a positive relationship with peak growing season NDVI (2nd half of July) values of the research site area $(r=0.43, p<0.05$, Fig. 3$)$, despite the small percentage cover of $S$. pulchra shrubs in the research area $(<5 \%$ S. pulchra cover, results not shown). No correlation of $S$. pulchra growth with biweekly NDVI values from other periods during the growing season was found (data not shown). The B. nana RES chronology did not correspond significantly with summer NDVI. No discernable trend in peak growing season NDVI during the available data span (1981-2006) was observed in our research area $(\mathrm{y}=$ $0.0026 x+0.6724)$. Inter-annual peak growing season NDVI variability could be partially explained by early summer temperature (17 June-19 July) $\left(R^{2}=0.42, p<0.01\right)$.

\section{Discussion}

We show that it is possible to construct ring-width chronologies from Arctic shrub species with markedly different growth forms. The B. nana RES chronology was used for climate-growth analysis for the time period 1948-2006, despite the low EPS values in the early part of the chronology due to the limited sample size and high variability in radial growth between $B$. nana individuals. The serial sectioning method allowed us to accurately cross-date ringwidth series within and between $B$. nana individuals. Correct 
Table 2. Pearson's correlation coefficients between shrub residual chronologies (Salix pulchra and Betula nana) and local climate variables temperature and precipitation (cumulative), derived from the meteorological station in Chokurdakh, for the period 1948-2006.

\begin{tabular}{lrr}
\hline Climate variables & \multicolumn{2}{c}{ Pearson's correlation coefficient } \\
& Salix pulchra & Betula nana \\
\hline Summer & & \\
Growing days (temperature $>5^{\circ} \mathrm{C}$ ) & $0.42^{* *}$ & 0.21 \\
Summer temperature (Jun-Aug) & $0.52^{* *}$ & 0.32 \\
Summer precipitation (Jun-Aug) & 0.03 & 0.06 \\
Early summer temperature (17 Jun-19 Jul) & $0.73^{* *}$ & $0.46^{* *}$ \\
Previous year's summer temperature (Jun-Aug) & -0.22 & -0.16 \\
Previous year's summer precipitation (Jun-Aug) & 0.16 & $0.42^{* *}$ \\
Winter/Spring & & \\
Snowmelt date & -0.22 & 0.10 \\
Winter temperature (Oct-Apr) & -0.10 & -0.07 \\
Winter precipitation (Oct-Apr) & 0.08 & 0.00 \\
Spring temperature (Mar-May) & -0.11 & -0.08 \\
Spring precipitation (Mar-May) & -0.08 & -0.05 \\
\hline
\end{tabular}

Growing days: yearly number of days with mean daily temperatures above $5^{\circ} \mathrm{C}$. Snow melt date: day of year when snow has melted (snowmelt data available for period $1992-2006$ ). Asterisks indicate the adjusted significance levels of the correlations, corrected for multiple testing: ${ }^{* *} p<0.01$

measurement and crossdating is independently verified by comparison with regional Larix spp. tree-ring chronologies.

Some dendroclimatological studies on Arctic Salix spp. shrubs do not observe a clear temperature effect on shrub growth (Schmidt et al., 2006; Zalatan and Gajewski, 2009), highlighting the importance to study multiple shrub species at many sites across the Arctic to assess the implications of climate changes on Arctic shrub growth rates. Shrub growth in our research site in NE-Siberia was found to be highly sensitive to early summer temperatures, as also observed for boreal tree growth in our research region (Hughes et al., 1999; Kirdyanov et al., 2003; Sidorova et al., 2010; Vaganov et al., 1999). The temperature during the period immediately following snowmelt (mid-June to mid-July) mainly determines radial growth for both $B$. nana and S. pulchra, in agreement with observations on controls on bud break timing for these shrub species (Pop et al., 2000). The lower correlation coefficient of $B$. nana radial growth to early summer temperature may be due to its specific growth strategy: under favorable growing conditions, B. nana is known to increase its growth mainly by producing many long shoots instead of producing mostly short shoots (Bret-Harte et al., 2001, 2002), which may result in a shift in growth allocation from radial growth of the older stems to vertical growth of the newly formed shoots. This growth strategy, together with the low-statured growth form of $B$. nana, with its many branches, may result in a reduced sensitivity of its radial growth to temperature. In comparison, S. pulchra is unable to greatly increase its vertical stem growth under favorable growing conditions (BretHarte et al., 2002). Nevertheless, the time window of maximum growth sensitivity to temperature was found to be iden- tical for B. nana and S. pulchra shrubs, showing that shrubs with markedly different growth forms can show a similar radial growth response.

No effect of summer precipitation on $B$. nana and $S$. pulchra growth was observed, which is consistent with a study on Larix spp. growth in N-Yakutia (Briffa et al., 2008; Sidorova et al., 2010). However, summer precipitation of the year preceding ring formation shows a positive correlation with $B$. nana growth, suggesting that its growth may be partly water-limited. As B. nana grows on relatively welldrained soils, it depends on precipitation for sufficient water supply, especially during late summer. A higher amount of precipitation during this period may alleviate drought stress and promote leaf bud development as well as assimilate storage and thus favor next year's growth. Wahren et al., (2005) observed in their Alaskan research site that deciduous shrub cover increased with increasing summer precipitation. They suggest that increased summer precipitation may result in a deeper active layer, which stimulates organic matter decomposition and possibly increases soil nitrogen availability that favors shrub growth. In comparison to B. nana shrubs, S. pulchra growth did not correspond with summer precipitation, most likely because $S$. pulchra grows at wetter micro sites than $B$. nana and is therefore less susceptible to temporarily dry conditions as a consequence of changes in summer precipitation.

Changes in snow depth may increase shrub growth via increased soil temperatures in shrub patches: their protruding branches capture drifting snow and thus increase the thickness of the snow layer in shrub-rich areas (Sturm et al., 2001a). A thicker snow pack has been observed 
Table 3. Summary of Pearson's correlation coefficients between the residual chronologies developed in this study (Salix pulchra and Betula nana) and 20 residual chronologies developed from tree-ring width data from sites in N-Yakutia, and one residual chronology developed from Salix lanata shrubs from W-Siberia over the common time span 1947-1990.

\begin{tabular}{|c|c|c|c|c|c|c|c|c|}
\hline \multirow[b]{2}{*}{ Site name } & \multicolumn{2}{|c|}{$\begin{array}{c}\text { Pearson's correlation } \\
\text { coefficients }\end{array}$} & \multirow[b]{2}{*}{ Latitude } & \multirow[b]{2}{*}{ Longitude } & \multirow[b]{2}{*}{ Elevation } & \multirow[b]{2}{*}{ Species } & \multirow[b]{2}{*}{$\begin{array}{c}\text { Distance } \\
\text { to site }(\mathrm{km})\end{array}$} & \multirow[b]{2}{*}{$\begin{array}{c}\text { Data } \\
\text { source }\end{array}$} \\
\hline & $\begin{array}{c}\text { Salix } \\
\text { pulchra }\end{array}$ & $\begin{array}{l}\text { Betula } \\
\text { nana }\end{array}$ & & & & & & \\
\hline Chokurdakh & $0.74 * *$ & $0.40 *$ & 70.17 & 148.03 & 50 & Larix dahurica & 75 & 1 \\
\hline North Yakutia & $0.78 * *$ & 0.37 & 69.30 & 147.00 & 80 & Larix dahurica & 170 & 2 \\
\hline Allagea River & 0.33 & 0.02 & 68.27 & 147.35 & 140 & Larix dahurica & 284 & 1 \\
\hline Andryuschkine & $0.65 * *$ & $0.42 * *$ & 69.17 & 154.46 & 50 & Larix dahurica & 323 & 1 \\
\hline Ayandina River & 0.30 & 0.26 & 68.25 & 143.10 & 45 & Larix dahurica & 332 & 1 \\
\hline Batagay & $0.49 * *$ & 0.04 & 70.15 & 138.10 & 80 & Larix dahurica & 356 & 1 \\
\hline Zhaschiviersk & 0.08 & 0.17 & 67.27 & 142.37 & 100 & Larix sibirica & 444 & 1 \\
\hline Srednie-Kolymsk & 0.06 & 0.13 & 67.15 & 153.42 & 50 & Larix dahurica & 472 & 1 \\
\hline Omoloya & $0.59 * *$ & 0.37 & 70.57 & 132.59 & 20 & Larix dahurica & 547 & 1 \\
\hline Tirekhtjakh River & 0.05 & -0.01 & 67.37 & 137.28 & 350 & Larix dahurica & 556 & 1 \\
\hline Rossocha River & 0.05 & 0.36 & 65.09 & 149.26 & 300 & Larix dahurica & 642 & 1 \\
\hline Cherskij & $0.41 *$ & $0.40 *$ & 68.48 & 163.03 & 300 & Larix dahurica & 654 & 1 \\
\hline Nulegeler River & $0.51 * *$ & 0.10 & 71.13 & 127.26 & 40 & Larix dahurica & 731 & 1 \\
\hline Ust-Nera & 0.00 & 0.20 & 64.32 & 143.07 & 600 & Larix dahurica & 746 & 1 \\
\hline Verchoyansk & 0.36 & -0.15 & 67.50 & 130.50 & 750 & Larix dahurica & 763 & 1 \\
\hline Shaguchan River & 0.17 & 0.08 & 63.35 & 148.17 & 1000 & Larix dahurica & 832 & 1 \\
\hline Seimchan River & 0.02 & 0.06 & 63.31 & 151.43 & 450 & Larix dahurica & 853 & 1 \\
\hline Uel Siktjach & 0.07 & -0.01 & 69.17 & 125.20 & 130 & Larix dahurica & 862 & 1 \\
\hline Bilibina & 0.33 & $0.47 *$ & 67.28 & 167.40 & 450 & Larix dahurica & 880 & 1 \\
\hline Balshoia Anui & 0.17 & 0.20 & 66.13 & 165.25 & 500 & Larix dahurica & 889 & 1 \\
\hline Nenets Autonomous Okrug & -0.01 & 0.19 & 68.40 & 58.30 & 40 & Salix lanata & 3131 & 3 \\
\hline
\end{tabular}

Asterisks indicate the adjusted significance levels of the correlations, corrected for multiple testing: ${ }^{*} P<0.05 ;{ }^{* *} P<0.01$.

Data sources:

${ }^{1}$ F. H. Schweingruber (http://www.wsl.ch/dendro/dendrodb.html);

${ }^{2}$ Hughes et al. (1999) (http://www.ncdc.noaa.gov/paleo/treering.html);

${ }^{3}$ Forbes et al. (2010).

Table 4. Statistics of multiple regression models explaining the similarities of the shrub chronologies from this study to the regional Larix spp. tree ring-width chronologies shown in Table 3.

\begin{tabular}{lcccccc}
\hline & $\begin{array}{c}\text { model parameters } \\
\text { (partial correlation) }\end{array}$ & $\begin{array}{c}\text { residuals } \\
\mathrm{df}\end{array}$ & $\mathrm{F}$ & $\begin{array}{c}\text { model } \\
R^{2}\end{array}$ & $\begin{array}{c}\text { adjusted } \\
\text { model } R^{2}\end{array}$ & p-value \\
\hline Salix pulchra & $\begin{array}{c}\text { latitude }(0.78) \\
\text { longitude }(0.45)\end{array}$ & 17 & 13.44 & 0.61 & 0.57 & 0.001 \\
Betula nana & $\begin{array}{c}\text { longitude }(0.73) \\
\text { elevation }(-0.60)\end{array}$ & 17 & 11.24 & 0.57 & 0.52 & 0.001 \\
\hline
\end{tabular}

The following explanatory variables were given as input to the regression models: distance from our research site, latitude, longitude and altitude of research sites. Non-significant parameters were deleted one at a time from the model. The dependent variables for the two regression models were the Pearson's correlation coefficients of the shrub residual chronologies (Salix pulchra and Betula nana) with the Larix spp. residual chronologies.

to lead to increased winter mineralization (Schimel et al., 2004). A thicker snowpack may also increase the active layer depth and soil nutrient concentrations during the spring season (Nowinski et al., 2010), which may favor further shrub growth and could thus create a positive feedback loop (Hallinger et al., 2010; Sturm et al., 2005b). In contrast, an increase in winter precipitation may also delay the onset of cambial activity as shown in Larix spp. trees in the Eurasian sub-Arctic (Kirdyanov et al., 2003; Vaganov et al., 1999). In this study we did not observe a correlation between shrub growth and winter precipitation for neither B. nana nor $S$. pulchra. This does not necessarily exclude a potential effect 
of local snow cover on shrub growth as winter precipitation is only one of several parameters (e.g. sublimation, wind dispersal, vegetation, local precipitation patterns, topography, aspect) affecting local snow height and associated soil thermal conditions (Yang et al., 2005).

A deeper snow pack, associated with taller shrubs, can alter the duration of the snow melt period (Pomeroy et al., 2006). In Greenland, a negative correlation has been observed between early spring snow cover extent and radial growth for Salix arctica shrubs (Schmidt et al., 2006). Nevertheless, the net effect of deeper snow on snow melt timing may be limited, because protruding shrub branches through the snow decrease the spring albedo, leading to increased absorption of solar radiation and higher snow melt rates (Sturm et al., 2005a). We observed no correlation of radial shrub growth with snow melt timing but we did observe a positive correlation with growing season length for S. pulchra. The relatively small number of years with snow melt data compared to the number of years with growing season length data may explain the difference in correlation strength with $S$. pulchra radial growth.

Our S. pulchra chronology correlated with Larix spp. tree chronologies from up to $880 \mathrm{~km}$ away from our research site, indicating that year-to-year growing conditions in the Siberian far east are similar for large territories (Vaganov and Kirdyanov, 2009). Similarities with Larix spp. chronologies were not explained by distance from our research site, but by latitude and longitude (S. pulchra) or longitude and elevation (B. nana). This suggests that climate-growth reconstructions from shrubs may be representative for large areas, but that these areas are restricted to climate zones defined by elevational and latitudinal boundaries.

Our B. nana chronology did not show a significant correlation with summer NDVI, which could be a result of a potential trade-off in growth allocation in $B$. nana shrubs between radial growth of old branches and vertical growth of newly formed stems. If growth of $B$. nana under favorable growing conditions is allocated relatively more to new shoot meristems and attached leaf buds, this may explain the asynchrony between radial growth of the older stems with the NDVI signal. In contrast to B. nana, S. pulchra radial growth did show a significant correlation with summer NDVI, despite the low cover of S. pulchra in our research area. The only other Siberian dendroclimatological study, using Salix lanata shrubs, shows a much higher correspondence with summer NDVI (Forbes et al., 2010). Correspondingly, in this study area the relative cover of shrubs was also much higher (>20\% cover of Salix spp., in comparison to the approximate $5 \%$ Salix spp. cover in our research site), probably resulting in a greater proportion of NDVI being explained by radial growth of Salix spp. Nevertheless, our results confirm that Salix spp. shrubs may be successfully used to track peak-growing season greening trends over a longer time period than the available satellite record.
Climate warming scenarios predict increases in summer temperature and summer precipitation in the Arctic (IPCC, 2007) that will impact future Arctic vegetation growth. One of the most prominent climate-induced vegetation changes is expected to be an increase in shrub growth. An increase in shrub cover can have important consequences for the Arctic ecosystem including changes in the surface energy balance (Chapin et al., 2005; Eugster et al., 2000; Euskirchen et al., 2009), soil organic matter turnover rates (Weintraub and Schimel, 2003, 2005) and tundra fire regimes (Higuera et al., 2008; Lantz et al., 2010; Racine et al., 2004). Furthermore, a higher shrub cover may lead to increased soil shading, thereby reducing the energy input into the soil, reducing summer permafrost thaw (Blok et al., 2010) and lower tundra soil carbon release during summer (I. H. Myers-Smith and D. S. Hik, unpublished manuscript). Our study area lies within the largest tundra zone in the world. Nevertheless, as of yet, no climate-growth studies on shrubs exist for this region.

We constructed growth chronologies of two widespread Arctic deciduous shrub species (Betula nana and Salix pulchra) that have not been used before in dendroclimatology. We show that deciduous shrub species with markedly different growth forms have a similar growth response to changes in climate. We provide the first climate-growth study on shrubs for East-Siberia, the largest tundra region in the world. The obtained shrub growth response to climate variability in the past increases our understanding of the mechanisms underlying current shrub expansion, which is required to predict future climate-driven tundra vegetation shifts. Our results indicate that the main climate drivers for shrub growth in our research area in NE-Siberia are early summer temperature and summer precipitation.

Acknowledgements. This study is partly financed by the Darwin Center for Biogeosciences and Wageningen Institute for Environment and Climate Research (WIMEK). We kindly thank Frida Keuper for the use of her Betula nana samples collected in the Kytalyk reserve. We are grateful to the staff of the BioGeoChemical Cycles of Permafrost Ecosystems Lab in Yakutsk for logistic support and to the staff of the Kytalyk State Resource Reservation for their permission and hospitality to conduct research in the Kytalyk reserve. We thank Annelein Meisner, Ake Nauta and both anonymous referees for their helpful comments on the manuscript and we thank Jasper van Ruijven for statistical advice. We thank Ellen Wilderink, Mathieu Decuyper and Paul Copini for lab assistance.

Edited by: T. Laurila 


\section{References}

ACIA: Arctic Climate Impact Assessment, Impacts of a Warming Arctic, Cambridge University Press, Cambridge, United Kingdom, 99-150, 2004.

Bär, A., Bräuning, A., and Löffler, J.: Dendroecology of dwarf shrubs in the high mountains of Norway - A methodological approach, Dendrochronologia, 24, 17-27, 2006.

Bär, A., Pape, R., Bräuning, A., and Löffler, J.: Growth-ring variations of dwarf shrubs reflect regional climate signals in alpine environments rather than topoclimatic differences, J. Biogeogr., 35, 625-636, 2008.

Bigelow, N. H., Brubaker, L. B., Edwards, M. E., Harrison, S. P., Prentice, I. C., Anderson, P. M., Andreev, A. A., Bartlein, P. J., Christensen, T. R., Cramer, W., Kaplan, J. O., Lozhkin, A. V., Matveyeva, N. V., Murray, D. F., McGuire, A. D., Razzhivin, V. Y., Ritchie, J. C., Smith, B., Walker, D. A., Gajewski, K., Wolf, V., Holmqvist, B. H., Igarashi, Y., Kremenetskii, K., Paus, A., Pisaric, M. F. J., and Volkova, V. S.: Climate change and Arctic ecosystems: 1. Vegetation changes north of 55 degrees $\mathrm{N}$ between the last glacial maximum, mid-Holocene, and present, J. Geophys. Res.-Atmos., 108, doi:10.1029/2002jd002558, 2003.

Blok, D., Heijmans, M. M. P. D., Schaepman-Strub, G., Kononov, A. V., Maximov, T. C., and Berendse, F.: Shrub expansion may reduce summer permafrost thaw in Siberian tundra, Glob. Change Biol., 16, 1296-1305, 2010.

Borner, A. P., Kielland, K., and Walker, M. D.: Effects of simulated climate change on plant phenology and nitrogen mineralization in Alaskan Arctic Tundra, Arct. Antarct. Alp. Res., 40, 27-38, 2008.

Bret-Harte, M. S., Shaver, G. R., Zoerner, J. P., Johnstone, J. F., Wagner, J. L., Chavez, A. S., Gunkelman, R. F., Lippert, S. C., and Laundre, J. A.: Developmental plasticy allows Betula nana to dominate tundra subjected to an altered environment, Ecology, 82, 18-32, 2001.

Bret-Harte, M. S., Shaver, G. R., and Chapin III, F. S.: Primary and Secondary Stem Growth in Arctic Shrubs: Implications for Community Response to Environmental Change, J. Ecol., 90, 251267, 2002.

Bret-Harte, M. S., Mack, M. C., Goldsmith, G. R., Sloan, D. B., DeMarco, J., Shaver, G. R., Ray, P. M., Biesinger, Z., and Chapin, F. S., III: Plant functional types do not predict biomass responses to removal and fertilization in Alaskan tussock tundra, J. Ecol., 96, 713-726, doi:10.1111/j.1365-2745.2008.01378.x, 2008.

Briffa, K. R., Shishov, V. V., Melvin, T. M., Vaganov, E. A., Grudd, H., Hantemirov, R. M., Eronen, M., and Naurzbaev, M. M.: Trends in recent temperature and radial tree growth spanning 2000 years across northwest Eurasia, Philos. T. R. Soc. B., 363, 2271-2284, 2008.

Büntgen, U. and Schweingruber, F. H.: Environmental change without climate change?, New Phytol., doi:10.1111/j.14698137.2010.03342.x, 2010.

Chapin III, F. S., Shaver, G. R., Giblin, A. E., Nadelhoffer, K. J., and Laundre, J. A.: Responses of Arctic tundra to experimental and observed changes in climate, Ecology, 76, 694-711, 1995.

Chapin III, F. S., Bret-Harte, M. S., Hobbie, S. E., and Zhong, H.: Plant Functional Types as Predictors of Transient Responses of Arctic Vegetation to Global Change, J. Veg. Sci., 7, 347-358, 1996.
Chapin III, F. S., Sturm, M., Serreze, M. C., McFadden, J. P., Key, J. R., Lloyd, A. H., McGuire, A. D., Rupp, T. S., Lynch, A. H., Schimel, J. P., Beringer, J., Chapman, W. L., Epstein, H. E., Euskirchen, E. S., Hinzman, L. D., Jia, G., Ping, C. L., Tape, K. D., Thompson, C. D. C., Walker, D. A., and Welker, J. M.: Role of Land-Surface Changes in Arctic Summer Warming, Science, 310, 657-660, doi:10.1126/science.1117368, 2005.

Cook, E., Briffa, K., Shiyatov, S., Mazepa, V., and Jones, P. D.: Data analysis, Methods of dendrochronology, 97-162, 1990.

Cook, E. R. and Peters, K.: The smoothing spline: a new approach to standardizing forest-interior tree-ring width series for dendroclimatic studies, Tree-Ring Bulletin, 41, 45-53, 1981.

Eugster, W., Rouse, W. R., Pielke Sr, R. A., McFadden, J., P., Baldocchi, D. D., Kittel, T. G. F., Chapin III, F. S., Liston, G., E., Vidale, P. L., Vaganov, E., and Chambers, S.: Land-atmosphere energy exchange in Arctic tundra and boreal forest: available data and feedbacks to climate, Glob. Change Biol., 6, 84-115, doi:10.1046/j.1365-2486.2000.06015.x, 2000.

Euskirchen, E. S., McGuire, A. D., Chapin III, F. S., Yi, S., and Thompson, C. C.: Changes in vegetation in northern Alaska under scenarios of climate change, 2003-2100: implications for climate feedbacks, Ecol. Appl., 19, 1022-1043, doi:10.1890/080806.1, 2009.

Forbes, B. C., Fauria, M. M., and Zetterberg, P.: Russian Arctic warming and "greening" are closely tracked by tundra shrub willows, Glob. Change Biol., 16, 1542-1554, 2010.

Fritts, H. C.: Tree Rings and Climate, London Academic Press, London, UK, 1976.

Goetz, S. J., Bunn, A. G., Fiske, G. J., and Houghton, R. A.: Satellite-observed photosynthetic trends across boreal North America associated with climate and fire disturbance, P. Natl. Acad. Sci., 102, 13521-13525, doi:10.1073/pnas.0506179102, 2005.

Goetz, S. J., Mack, M. C., Gurney, K. R., Randerson, J. T., and Houghton, R. A.: Ecosystem responses to recent climate change and fire disturbance at northern high latitudes: observations and model results contrasting northern Eurasia and North America, Environ. Res. Lett., 1-9, 045031, doi:10.1088/17489326/2/4/045031, 2007.

Grissino-Mayer, H. D.: Evaluating crossdating accuracy: A manual and tutorial for the computer program COFECHA, Tree-Ring Res., 57, 205-221, 2001.

Hallinger, M., Manthey, M., and Wilmking, M.: Establishing a missing link: warm summers and winter snow cover promote shrub expansion into alpine tundra in Scandinavia, New Phytol., 186, 890-899, 2010.

Higuera, P. E., Brubaker, L. B., Anderson, P. M., Brown, T. A., Kennedy, A. T., and $\mathrm{Hu}, \mathrm{F}$. S.: Frequent fires in ancient shrub tundra: Implications of paleorecords for arctic environmental change, PLoS ONE, 3, 2008.

Hobbie, S. E. and Chapin III, F. S.: The response of tundra plant biomass, aboveground production, nitrogen, and $\mathrm{CO}_{2}$ flux to experimental warming, Ecology, 79, 1526-1544, 1998.

Holmes, R. L.: Computer-assisted quality control in tree-ring dating and measurement, Tree-Ring Bulletin, 43, 69-78, 1983.

Hudson, J. M. G. and Henry, G. H. R.: Increased plant biomass in a High Arctic heath community from 1981 to 2008, Ecology, 90, 2657-2663, doi:10.1890/09-0102.1, 2009. 
Hughes, M. K., Vaganov, E. A., Shiyatov, S., Touchan, R., and Funkhouser, G.: Twentieth-century summer warmth in northern Yakutia in a 600-year context, The Holocene, 9, 629-634, doi:10.1191/095968399671321516, 1999.

Hultén, E.: Flora of Alaska and neighboring territories: a manual of the vascular plants, Stanford University Press, 1968.

IPCC: Climate Change 2007: The Physical Science Basis. Contribution of Working Group I to the Fourth Assessment Report of the Intergovernmental Panel on Climate Change, Cambridge University Press, Cambridge, United Kingdom and New York, NY, USA, 996, 2007.

Jia, G. J., Epstein, H. E., and Walker, D. A.: Vegetation greening in the canadian arctic related to decadal warming, J. Environ. Mon., 11, 2231-2238, 2009.

Kirdyanov, A., Hughes, M., Vaganov, E., Schweingruber, F., and Silkin, P.: The importance of early summer temperature and date of snow melt for tree growth in the Siberian Subarctic, Trees Structure and Function, 17, 61-69, 2003.

Klein Tank, A. M. G., Wijngaard, J. B., Können, G. P., Böhm, R., Demarée, G., Gocheva, A., Mileta, M., Pashiardis, S., Hejkrlik, L., Kern-Hansen, C., Heino, R., Bessemoulin, P., MüllerWestermeier, G., Tzanakou, M., Szalai, S., Pálsdóttir, T., Fitzgerald, D., Rubin, S., Capaldo, M., Maugeri, M., Leitass, A., Bukantis, A., Aberfeld, R., Van Engelen, A. F. V., Forland, E., Mietus, M., Coelho, F., Mares, C., Razuvaev, V., Nieplova, E., Cegnar, T., Antonio López, J., Dahlström, B., Moberg, A., Kirchhofer, W., Ceylan, A., Pachaliuk, O., Alexander, L. V., and Petrovic, P.: Daily dataset of 20th-century surface air temperature and precipitation series for the European Climate Assessment, Int. J. Climatol., 22, 1441-1453, 2002.

Kolishchuk, V. G.: Dendroclimatological study of prostrate woody plants., in: Methods of dendrochronology. Applications in the environmental sciences., edited by: Cook, E. R. and Kairiukstis, L. A., Kluwer, London, U.K., 51-55, 1990.

Lantz, T. C., Gergel, S. E., and Henry, G. H. R.: Response of green alder (Alnus viridis subsp. fruticosa) patch dynamics and plant community composition to fire and regional temperature in north-western Canada, J. Biogeogr., 37, 1597-1610, 2010.

McGuire, A. D., Chapin III, F. S., Walsh, J. E., and Wirth, C.: Integrated Regional Changes in Arctic Climate Feedbacks: Implications for the Global Climate System, Annu. Rev. Env. Resour., 31, 61-91, doi:10.1146/annurev.energy.31.020105.100253, 2006.

Müller, S., Tarasov, P. E., Andreev, A. A., and Diekmann, B.: Late Glacial to Holocene environments in the present-day coldest region of the Northern Hemisphere inferred from a pollen record of Lake Billyakh, Verkhoyansk Mts, NE Siberia, Clim. Past, 5, 73-84, doi:10.5194/cp-5-73-2009, 2009.

Myers-Smith, I. H. and Hik, D. S.: Canopy shading offsets snow trapping influences on tundra soil temperatures: Implications for an advancing shrubline, unpublished manuscript, 2010.

Nowinski, N. S., Taneva, L., Trumbore, S. E., and Welker, J. M.: Decomposition of old organic matter as a result of deeper active layers in a snow depth manipulation experiment, Oecologia, 163, 785-792, 2010.

Olofsson, J., Oksanen, L., Callaghan, T., Hulme, P. E., Oksanen, T., and Suominen, O.: Herbivores inhibit climate-driven shrub expansion on the tundra, Glob. Change Biol., 15, 2681-2693, 2009.
Panyushkina, I. P., Hughes, M. K., Vaganov, E. A., and Munro, M. A. R.: Summer temperature in northeastern Siberia since 1642 reconstructed from tracheid dimensions and cell numbers of Larix cajanderi, Can. J. Forest Res., 33, 1905-1914, 2003.

Pomeroy, J. W., Bewley, D. S., Essery, R. L. H., Hedstrom, N. R., Link, T., Granger, R. J., Sicart, J. E., Ellis, C. R., and Janowicz, J. R.: Shrub tundra snowmelt, Hydrol. Process., 20, 923-941, 2006.

Pop, E. W., Oberbauer, S. F., and Starr, G.: Predicting vegetative bud break in two arctic deciduous shrub species, Salix pulchra and Betula nana, Oecologia, 124, 176-184, 2000.

Racine, C., Jandt, R., Meyers, C., and Dennis, J.: Tundra fire and vegetation change along a hillslope on the Seward Peninsula, Alaska, U.S.A, Arct. Antarct. Alp. Res., 36, 1-10, 2004.

Rayback, S. A. and Henry, G. H. R.: Reconstruction of summer temperature for a Canadian high arctic site from retrospective analysis of the dwarf shrub, Cassiope tetragona, Arct. Antarct. Alp. Res., 38, 228-238, 2006.

Raynolds, M. K., Comiso, J. C., Walker, D. A., and Verbyla, D.: Relationship between satellite-derived land surface temperatures, arctic vegetation types, and NDVI, Remote Sens. Environ., 112, 1884-1894, 2008.

Rozema, J., Weijers, S., Broekman, R., Blokker, P., Buizer, B., Werleman, C., El Yaqine, H., Hoogedoorn, H., Mayoral Fuertes, M., and Cooper, E.: Annual growth of Cassiope tetragona as a proxy for Arctic climate: developing correlative and experimental transfer functions to reconstruct past summer temperature on a millennial time scale, Glob. Change Biol., 15, 1703-1715, 2009.

Schimel, J. P., Bilbrough, C., and Welker, J. M.: Increased snow depth affects microbial activity and nitrogen mineralization in two Arctic tundra communities, Soil Biol. Biochem., 36, 217227, doi:10.1016/j.soilbio.2003.09.008, 2004.

Schmidt, N. M., Baittinger, C., and Forchhammer, M. C.: Reconstructing century-long snow regimes using estimates of high arctic Salix arctica radial growth, Arct. Antarct. Alp. Res., 38, 257 262, 2006.

Schmidt, N. M., Baittinger, C., Kollmann, J., and Forchhammer, M. C.: Consistent Dendrochronological Response of the Dioecious Salix arctica to Variation in Local Snow Precipitation across Gender and Vegetation Types, Arct. Antarct. Alp. Res., 42, 471475, doi:10.1657/1938-4246-42.4.471, 2010.

Sidorova, O. V., Siegwolf, R. T. W., Saurer, M., Naurzbaev, M. M., Shashkin, A. V., and Vaganov, E. A.: Spatial patterns of climatic changes in the Eurasian north reflected in Siberian larch tree-ring parameters and stable isotopes, Glob. Change Biol., 16, 10031018, 2010.

Sturm, M., McFadden, J. P., Liston, G. E., Chapin III, F. S., Racine, C. H., and Holmgren, J.: Snow-shrub interactions in Arctic tundra: A hypothesis with climatic implications, J. Clim., 14, 336344, 2001a.

Sturm, M., Racine, C., and Tape, K. D.: Climate change: Increasing shrub abundance in the Arctic, Nature, 411, 546-547, $2001 \mathrm{~b}$.

Sturm, M., Douglas, T., Racine, C., and Liston, G. E.: Changing snow and shrub conditions affect albedo with global implications, J. Geophys. Res., 110, G01004.01001-G01004.01013, 2005a.

Sturm, M., Schimel, J. P., Michaelson, G. J., Welker, J. M., Oberbauer, S. F., Liston, G. E., Fahnestock, J. T., and Romanovsky, V. E.: Winter Biological Processes Could Help Convert Arctic 
Tundra to Shrubland, BioScience, 55, 17-26, 2005 b.

Tape, K., Sturm, M., and Racine, C.: The evidence for shrub expansion in Northern Alaska and the Pan-Arctic, Glob. Change Biol., 12, 686-702, doi:10.1111/j.1365-2486.2006.01128.x, 2006.

Tucker, C. J., Pinzon, J. E., Brown, M. E., Slayback, D. A., Pak, E. W., Mahoney, R., Vermote, E. F., and El Saleous, N.: An extended AVHRR 8-km NDVI dataset compatible with MODIS and SPOT vegetation NDVI data, International J. Remote Sens., 26, 4485-4498, 2005.

Vaganov, E. A., Hughes, M. K., Kirdyanov, A. V., Schweingruber, F. H., and Silkin, P. P.: Influence of snowfall and melt timing on tree growth in subarctic Eurasia, Nature, 400, 149-151, 1999.

Vaganov, E. A., and Kirdyanov, A. V.: Dendrochronology of Larch Trees Growing on Siberian Permafrost, in: Permafrost Ecosystems, edited by: Caldwell, M. M., Heldmaier, G., Jackson, R. B., Lange, O. L., Mooney, H. A., Schulze, E. D., and Sommer, U., Ecological Studies, Springer Netherlands, 347-363, 2009.

van der Molen, M. K., van Huissteden, J., Parmentier, F. J. W., Petrescu, A. M. R., Dolman, A. J., Maximov, T. C., Kononov, A. V., Karsanaev, S. V., and Suzdalov, D. A.: The growing season greenhouse gas balance of a continental tundra site in the Indigirka lowlands, NE Siberia, Biogeosciences, 4, 985-1003, doi:10.5194/bg-4-985-2007, 2007.

Verhoeven, K. J. F., Simonsen, K. L., and McIntyre, L. M.: Implementing false discovery rate control: Increasing your power, Oikos, 108, 643-647, 2005.

Wahren, C.-H. A., Walker, M. D., and Bret-Harte, M. S.: Vegetation responses in Alaskan arctic tundra after 8 years of a summer warming and winter snow manipulation experiment, Glob. Change Biol., 11, 537-552, doi:10.1111/j.13652486.2005.00927.x, 2005.

Walker, D. A., Raynolds, M. K., Daniels, F. J. A., Einarsson, E., Elvebakk, A., Gould, W. A., Katenin, A. E., Kholod, S. S., Markon, C. J., Melnikov, E. S., Moskalenko, N. G., Talbot, S. S., and Yurtsev, B. A.: The Circumpolar Arctic Vegetation Map, J. Veg. Sci., 16, 267-282, 2005.
Walker, M. D., Wahren, C. H., Hollister, R. D., Henry, G. H. R., Ahlquist, L. E., Alatalo, J. M., Bret-Harte, M. S., Calef, M. P., Callaghan, T. V., Carroll, A. B., Epstein, H. E., Jonsdottir, I. S., Klein, J. A., Magnusson, B., Molau, U., Oberbauer, S. F., Rewa, S. P., Robinson, C. H., Shaver, G. R., Suding, K. N., Thompson, C. C., Tolvanen, A., Totland, O., Turner, P. L., Tweedie, C. E., Webber, P. J., and Wookey, P. A.: Plant community responses to experimental warming across the tundra biome, Proc. Natl. Acad. Sci. USA, 103, 1342-1346, doi:10.1073/pnas.0503198103, 2006.

Weintraub, M. N. and Schimel, J. P.: Interactions between Carbon and Nitrogen Mineralization and Soil Organic Matter Chemistry in Arctic Tundra Soils, Ecosystems, 6, 129-143, doi:10.1007/s10021-002-0124-6, 2003.

Weintraub, M. N. and Schimel, J. P.: Nitrogen cycling and the spread of shrubs control changes in the carbon balance of arctic tundra ecosystems, Bioscience, 55, 408-415, 2005.

Wigley, T. M. L., Briffa, K. R., and Jones, P. D.: On the average value of correlated time series with applications in dendroclimatology and hydrometeorology, J. Clim. Appl. Meteorol., 23, 201-213, 1984.

Woodcock, H. and Bradley, R. S.: Salix arctica (Pall.): its potential for dendrochronological studies in the High Arctic, Dendrochronologia, 12, 11-22, 1994.

Wookey, P. A., Aerts, R., Bardgett, R. D., Baptist, F., Bråthen, K. A., Cornelissen, J. H. C., Gough, L., Hartley, I. P., Hopkins, D. W., Lavorel, S., and Shaver, G. R.: Ecosystem feedbacks and cascade processes: understanding their role in the responses of Arctic and alpine ecosystems to environmental change, Glob. Change Biol., 15, 1153-1172, 2009.

Yang, D., Kane, D., Zhang, Z., Legates, D., and Goodison, B.: Bias corrections of long-term (1973-2004) daily precipitation data over the northern regions, Geophys. Res. Lett., 32, 1-5, 2005.

Zalatan, R. and Gajewski, K.: Dendrochronological Potential of Salix alaxensis from the Kuujjua River Area, Western Canadian Arctic, Tree-Ring Res., 62, 75-82, 2009. 